\title{
The Staphylococcus aureus allelic genetic loci for serotype 5 and 8 capsule expression contain the type-specific genes flanked by common genes
}

\author{
Subrata Sau, ${ }^{1}$ Navneet Bhasin, ${ }^{2}$ Elisabeth R. Wann, ${ }^{3}$ Jean C. Lee, ${ }^{2}$ \\ Timothy J. Foster ${ }^{3}$ and Chia Y. Lee' \\ Author for correspondence: Chia Y. Lee. Tel: +1913 588 7156. Fax: +19135887295. \\ e-mail: clee@kumc.edu
}

1 Department of Microbiology, Molecular Genetics and Immunology, University of Kansas Medical Center, Kansas City, Kansas 66160, USA

2 Channing Laboratory, Department of Medicine, Brigham and Women's Hospital and Harvard Medical School, Boston, Massachusetts 02115, USA

3 Microbiology Department, Moyne Institute, Trinity College, Dublin 2, Ireland
The nucleotide sequences of two gene clusters, cap5 and cap8, involved in the synthesis of Staphylococcus aureus type 5 and type 8 capsular polysaccharides (CPs), respectively, were determined. Each gene cluster contained 16 ORFs, which were named cap5A through cap5P for type 5 CP and cap8A through cap8P for type $8 \mathrm{CP}$. The cap5 and cap8 loci were allelic and were mapped to the Smal-G fragment in the standard Smal map of Staph. aureus strain NCTC 8325. The predicted gene products of cap5A through cap5G and cap $5 L$ through cap5P are essentially identical to those of cap8A through cap8G and cap8L through cap8P, respectively, with very few amino acid substitutions. Four ORFs located in the central region of each locus are type-specific. A comparison of the predicted amino acid sequences of cap5 and cap8 with sequences found in the databases allowed tentative assignment of functions to 15 of the 16 ORFs. The majority of the capsule genes are likely to be involved in amino sugar synthesis; the remainder are likely to be involved in sugar transfer, capsule chain-length regulation, polymerization and transport.

Keywords: polysaccharide, capsule, Staphylococcus aureus, cap5 and cap8 gene clusters

\section{INTRODUCTION}

Staphylococcus aureus is an important human and animal pathogen. More than $90 \%$ of clinical isolates of this bacterium produce capsular polysaccharides (CPs), which have been classified into 11 serotypes (Karakawa \& Vann, 1982; Sompolinsky et al., 1985). Serotype 1 and 2 strains of Staph. aureus are highly encapsulated (Wilkinson, 1983) but are rarely isolated from any source. Type 1 and type 2 CPs have been shown to be important virulence factors (Lee et al., 1987; Lin et al., 1994; Melly et al., 1974; Peterson et al., 1978). Most Staph. aureus strains elaborate microcapsules smaller than those produced by strains of serotype 1 and 2 . Strains producing type 5 and type 8 capsules account for about $80 \%$ of clinical isolates (Albus et al., 1988; Arbeit

\footnotetext{
Abbreviation: $\mathrm{CP}$, capsular polysaccharide
}

The GenBank accession numbers for the nucleotide sequences of the cap5 and cap8 gene clusters reported in this paper are U81973 and U73374, respectively. et al., 1984; Hochkeppel et al., 1987; Karakawa et al., 1985; Poutrel et al., 1988). The role of type 5 and type 8 capsules in virulence remains controversial (Albus et al., 1991; Baddour et al., 1992; Nemeth \& Lee, 1995; Karakawa et al., 1988; Xu et al., 1992). Nonetheless, recent studies (Fattom et al., 1996; Lee et al., 1996) have shown that type 5 capsules may be the target of antibodies that protect against experimental Staph. aureus infections.

The biochemical structures of type $1 \mathrm{CP}$ (CP1), type 2 CP (CP2), type 5 CP (CP5) and type 8 CP (CP8) have been determined; each contains hexosaminouronic acid sugars (Fournier et al., 1984; Moreau et al., 1990; Murthy et al., 1983; Hanessian \& Haskell, 1964). As shown below, CP5 and CP8 are very similar and differ only in the position of $\mathrm{O}$-acetyl groups and the linkages between the amino sugars. CP1, CP5 and CP8 also have a common sugar, $\mathrm{N}$-acetylfucosamine (2-acetamido-2,6dideoxygalactose). The repeating units are:

CP1: 4)- $\alpha$-D-GalNAcA $p-(1 \rightarrow 4)-\alpha-D-G a l N A c A p-(1 \rightarrow$ $3)-\alpha$-D-FucNAc $p-(1 \rightarrow$ 
(A taurine residue is linked by an amide bond to every fourth $\mathrm{D}$-GalNAcA $p$ residue.)

CP2: 4)- $\beta$-D-GlcNAcA $p-(1 \rightarrow 4)-\beta$-D-GlcN-(N-acetylalanyl $)-\mathrm{AcA} p-(1 \rightarrow$

CP5 : 4)-3-O-Ac- $\beta$-D-ManNAcA $p-(1 \rightarrow 4)-\alpha-\mathrm{L}-F u c N A c p-$ $(1 \rightarrow 3)-\beta$-D-FucNAc $p$ - $(1 \rightarrow$

CP8: 3$)-4-O-A c-\beta$-D-ManNAcA $p-(1 \rightarrow 3)-\alpha-\mathrm{L}-\mathrm{FucNAc} p-$ $(1 \rightarrow 3)-\beta$-D-FucNAc $p$ - $(1 \rightarrow$

Genetic studies of the CPs of Staph. aureus have only recently been reported. The cap1 gene cluster required for CP1 synthesis has been cloned and sequenced (Lee, 1992; Lin et al., 1994), and the cap5 and cap 8 gene clusters have been cloned and partially characterized (Lee et al., 1994; Sau \& Lee, 1996; Sau et al., 1997). Southern hybridization studies have revealed that the cap5 and cap8 gene clusters have two common regions flanking a type-specific region; this finding suggests that these two gene clusters are allelic. In type 1 strain $M$, in addition to the cap1 gene cluster, a cap locus with extensive homology to the cap 8 gene cluster has been identified, indicating that the cap1 and cap8 loci are not allelic (Sau \& Lee, 1996). In this communication, we report the mapping of the cap5(8) locus on the Staph. aureus chromosome and the nucleotide sequences of the cap5 and cap8 gene clusters. We show that the DNA sequences containing 12 of the 16 ORFs of the cap5 and cap8 gene clusters are almost identical. By analogy with homologous genes from other bacteria, we discuss the possible functions of these ORFs in CP5 and CP8 biosynthesis.

\section{METHODS}

Strains and growth conditions. The bacterial strains and plasmids used are listed in Table 1. Escherichia coli strains were grown in Luria-Bertani broth or agar (Difco) and were used for propagating and harvesting plasmids. Staph. aureus strains Newman and Reynolds were used to clone and sequence the cap5 gene cluster. Staph. aureus strain Becker, which produces CP8, was used as the source of DNA for sequencing the cap8 gene cluster.

DNA manipulations. DNA manipulations were performed as described by Sambrook et al. (1989). Plasmid DNA was isolated by the method of Birnboim (1983) and further purified by $\mathrm{CsCl}$ /ethidium bromide density gradient centrifugation or by use of either the Wizard (Promega) or the Qiagen plasmid kit. Restriction enzymes and other enzymes used in the study were purchased from Gibco-BRL and New England Biolabs. Field-inversion gel electrophoresis was performed as described by Goering \& Winters (1992).

DNA sequencing and analysis. An $\sim 12.5 \mathrm{~kb}$ region of the cap5 5 genes was subcloned from pJCL19 (carrying an $\sim 34 \mathrm{~kb}$ contiguous fragment encompassing the cap5 genes from strain Reynolds; Lee et al., 1994) in vectors pGEM7Z(+) or pLI50. An $\sim 7.1 \mathrm{~kb}$ region of the cap5 genes was also cloned from strain Newman. Nested sets of deletions were generated with an Erase-a-base kit (Promega) and sequenced with an automated DNA sequencer (model 373A) and Taq DyeDeoxy Terminator Cycle sequencing kits (Applied Biosystems). To sequence the chromosomal locus containing cap8 genes,

Table 1. Bacterial strains and plasmids

\begin{tabular}{|c|c|c|}
\hline Strain or plasmid & Relevant characteristics & Source or reference \\
\hline \multicolumn{3}{|c|}{ Staph. aureus strains } \\
\hline 8325 & & $\begin{array}{l}\text { J. J. Iandolo, Kansas State } \\
\text { University, Manhattan, } \\
\text { KS, USA }\end{array}$ \\
\hline M & Type 1 capsule strain & $\begin{array}{l}\text { J. H. Hash, Vanderbilt } \\
\text { University, Nashville, } \\
\text { TN, USA }\end{array}$ \\
\hline Smith & Type 2 capsule strain & ATCC 13709 \\
\hline Reynolds & Type 5 capsule strain & Karakawa \& Vann (1982) \\
\hline Newman & Type 5 capsule strain & NCTC 8178 \\
\hline Becker & Type 8 capsule strain & Karakawa \& Vann (1982) \\
\hline \multicolumn{3}{|l|}{ E. coli strains } \\
\hline HB101 & recA13 hsdS20 ara-14 proA2 lacY1 galK2 xyl-5 mtl-1 supE44 rpsL20 & $\begin{array}{l}\text { J. Lutkenhaus, University of } \\
\text { Kansas Medical Center, } \\
\text { Kansas City, KS, USA }\end{array}$ \\
\hline JM109 & $\begin{array}{l}\text { recA1 end } 11 \text { gyrA96 thi hsdR17 supE44 relA } 1 \Delta(\text { lac-proAB }) / \mathrm{F}^{\prime}(\text { traD36 } \\
\left.\text { proAB }{ }^{+} \text {lacI }{ }^{q} \text { lacZ } \Delta \mathrm{M} 15\right)\end{array}$ & $\begin{array}{l}\text { Yanisch-Perron et al. } \\
\text { (1985) }\end{array}$ \\
\hline XL1-Blue & $\begin{array}{l}\text { recA1 end } A 1 \text { gyrA96 thi hsdR17 supE44 relA1 } \Delta(\text { lac-proAB }) / \mathrm{F}^{\prime}(\text { traD36 } \\
\left.\text { proAB } \text { lacl }^{\mathrm{q}} \text { lacZ } \Delta \mathrm{M} 15 \operatorname{Tn} 10\right)\end{array}$ & Sambrook et al. (1989) \\
\hline \multicolumn{3}{|l|}{ Plasmids } \\
\hline pGEM7Z(+) & Cloning vector & Promega \\
\hline pBluescript & Cloning vector & Stratagene \\
\hline pLI50 & E. coli-Staph. aureus shuttle cloning vector & Lee et al. (1991) \\
\hline pJCL19 & $34 \mathrm{~kb}$ fragment of strain Reynolds DNA cloned in BamHI site of $\mathrm{pHC79}$ & Lee et al. (1994) \\
\hline
\end{tabular}


several overlapping fragments from a contiguous $18.5 \mathrm{~kb}$ DNA fragment (Sau \& Lee, 1996) were generated by restriction enzymes and subcloned into suitable sites in pBluescript $\mathrm{KS}(+)$. Nested sets of deletions from each subclone were generated by exonuclease III. Sequencing was performed by the method of Sanger et al. (1977) with a sequencing kit from US Biochemical.

Sequences were assembled and analysed with the Wisconsin Genetics Computer Group software package. Protein homology searches from the databases were conducted with the BLAST network service at the National Center for Biotechnology Information according to the method of Altschul et al. (1990). Protein hydrophobicity was calculated by the method of Kyte \& Doolittle (1982), with windows set at nine amino acids. Alignment of amino acids was performed with the clustal program (Higgins \& Sharp, 1988). The method of Klein et al. (1985) was used for predicting potential transmembrane segments. In cases for which the analogous gene products from $c a p 5$ and $c a p 8$ genes were virtually identical, only the gene products from the cap5 gene cluster were included in protein alignments and hydrophobicity profile comparisons.

\section{RESULTS AND DISCUSSION}

\section{Nucleotide sequences of the cap5 and cap8 gene clusters}

We previously reported that all 28 Cap $8^{-}$mutants derived from Staph. aureus strain Becker were complemented by plasmid subclones from a contiguous $20.5 \mathrm{~kb}$ DNA fragment of strain Becker (Sau \& Lee, 1996). This result suggests that the majority of the cap 8 genes affecting CP8 biosynthesis are clustered in this region of the chromosome. The nucleotide sequence of $\sim 18.5 \mathrm{~kb}$ within the $20.5 \mathrm{~kb}$ DNA region was determined. Sixteen ORFs in a $17.5 \mathrm{~kb}$ region, designated cap8A through cap8P (Fig. 1), were found to be tightly clustered and transcribed in one orientation.

The cap5 locus was initially identified in strain Reynolds by Tn918 mutagenesis (Lee et al., 1994) and in strain Newman by Tn917 mutagenesis (E. R. Wann \& T. J. Foster, unpublished). DNA fragments flanking the Tn918 insertion sites were used to screen a cosmid library prepared from wild-type strain Reynolds. Similarly, sequences flanking Tn917 in strain Newman were cloned and used as probes against a lambda library prepared from strain Newman. A 7•1 kb DNA segment encompassing cap5A through cap5G was sequenced from strain Newman, and a $12.6 \mathrm{~kb}$ DNA segment including cap $5 F$ through cap5P was sequenced from strain Reynolds. The region of overlapping sequence between the two strains was $1.55 \mathrm{~kb}$ in length and included most of cap5F and half of cap5G. Six nucleotide differences between the two strains were found in the overlapping segment, and five of these differences resulted in no change in the amino acid sequences of the deduced proteins. One variation between strains Reynolds and Newman was in amino acid 196 of Cap5G, which was shown to be serine in the former case and proline in the latter. At the equivalent position in Cap8G, the deduced amino acid was proline.

Sequence analysis of the combined $18 \cdot 1 \mathrm{~kb}$ region from serotype 5 strains revealed 16 contiguous ORFs that were transcribed in the same orientation and were named cap5A through cap5P (Fig. 1). Comparison of the nucleotide sequences of the cap 5 and $c a p 8$ genes revealed that each of the gene clusters could be divided into three regions. Regions 1 and 3 were highly homologous with $98.1 \%$ and $98.6 \%$ identities, respectively. In contrast, the central regions showed insignificant homology (less than $43 \%$ ). The overall G+C content in the coding regions of the cap5 and cap8 loci was $32.6 \mathrm{~mol} \%$ and $32.9 \mathrm{~mol} \%$, respectively - values typical of the Staph. aureus genome (Oeding, 1983). However, a lower G +C content of the sequences of the four ORFs located in the type-specific regions (average of $29.1 \mathrm{~mol} \%$ for cap $5 \mathrm{H}$ to cap $5 \mathrm{~K}$ and $28.5 \mathrm{~mol} \%$ for cap $8 \mathrm{H}$ to $c a p 8 \mathrm{~K}$ ) suggested that these type-specific genes could have been derived from other organisms with a lower G $+C D N A$ content.

\section{Chain-length determination genes}

Cap5A and Cap8A show significant homology to EpsC of Streptococcus thermophilus (Stingele et al., 1996) and

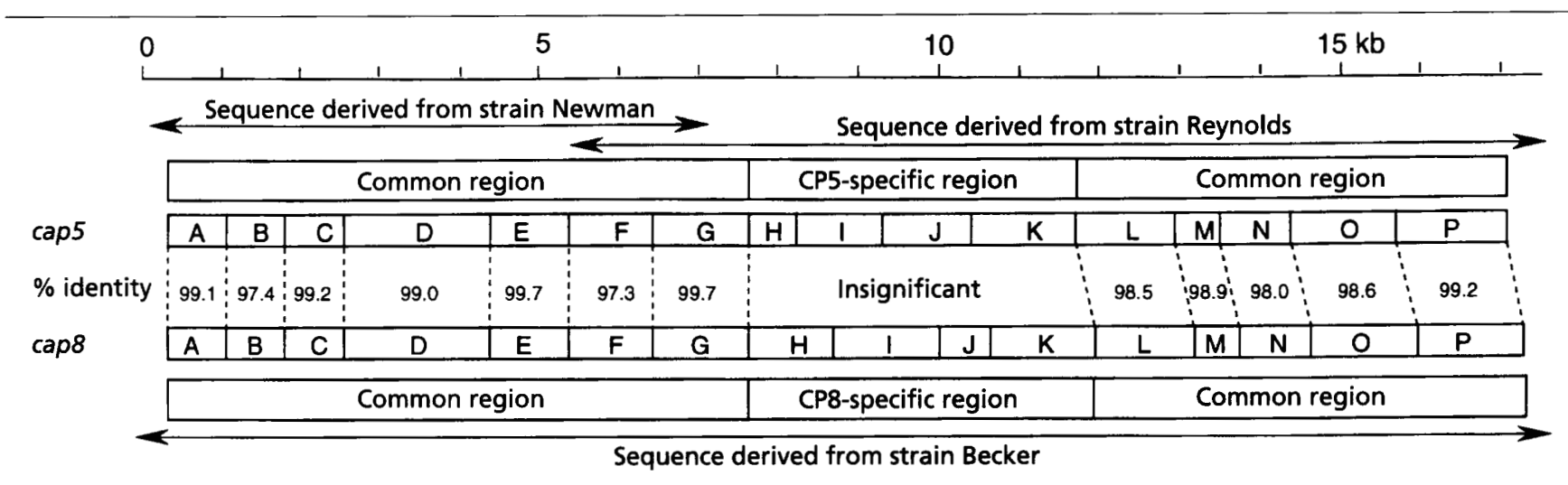

Fig. 1. Comparison of Staph. aureus cap5 and cap8 gene clusters. The cap5 sequence was derived from strains Newman and Reynolds and the cap8 sequence from strain Becker as shown. Gene designations are shown in boxes. Percentage identity indicates the amino acid identity of the deduced proteins of the two clusters. Both gene clusters are transcribed from left to right. 
Table 2. Homology of putative gene products with related sequences in the databases

\begin{tabular}{|c|c|c|c|}
\hline ORF & Size & Homologous protein $\nmid$ & References \\
\hline $\operatorname{cap5}(8) A$ & 222 & $\begin{array}{l}\text { Staphylococcus aureus Cap1A (63/167), type } 1 \text { CP synthesis } \\
\text { Streptococcus thermophilus EpsC (33/183), probable chain-length } \\
\text { regulator } \\
\text { Streptococcus pneumoniae CpsC (32/183), probable chain-length } \\
\text { regulator }\end{array}$ & $\begin{array}{l}\text { Lin et al. (1994) } \\
\text { Stingele et al. (1996) }\end{array}$ \\
\hline $\operatorname{cap} 5(8) B$ & 228 & $\begin{array}{l}\text { Staph. aureus Cap1B }(62 / 228) \text {, type } 1 \mathrm{CP} \text { synthesis } \\
\text { Strep. pneumoniae } \mathrm{CpsD}(41 / 117) \text {, probable chain-length regulator } \\
\text { Strep. thermophilus EpsD ( } 40 / 117) \text {, probable chain-length regulator } \\
\text { Rhizobium meliloti ExoP }(30 / 113) \text {, chain-length regulator }\end{array}$ & $\begin{array}{l}\text { Lin et al. (1994) } \\
\text { Guidolin et al. (1994) } \\
\text { Stingele et al. (1996) } \\
\text { Becker et al. (1995) }\end{array}$ \\
\hline $\operatorname{cap} 5(8) \mathrm{C}$ & 254 & $\begin{array}{l}\text { Staph. aureus Cap1C (59/254), type } 1 \text { CP synthesis } \\
\text { Strep. thermophilus EpsB (31/165), exopolysaccharide synthesis } \\
\text { Strep. pneumoniae CpsB (31/165), type 19F CP synthesis }\end{array}$ & $\begin{array}{l}\text { Lin et al. (1994) } \\
\text { Stingele } \text { et al. (1996) } \\
\text { Guidolin et al. (1994) }\end{array}$ \\
\hline $\operatorname{cap} 5(8) D$ & 607 & $\begin{array}{l}\text { Staph. aureus Cap1D }(72 / 578) \text {, type } 1 \text { CP synthesis } \\
\text { Yersinia enterocolitica } \operatorname{TrsG}(59 / 192) \text {, lipopolysaccharide outer core } \\
\text { synthesis } \\
\text { Vibrio cholerae ORF11 (62/114), O139 antigen synthesis } \\
\text { Bordetella pertussis Bp1L }(55 / 195) \text {, lipopolysaccharide synthesis }\end{array}$ & $\begin{array}{l}\text { Lin et al. (1994) } \\
\text { Skurnik et al. (1995) } \\
\text { Comstock et al. (1996) } \\
\text { Allen \& Maskell (1996) }\end{array}$ \\
\hline $\operatorname{cap} 5(8) E$ & 342 & Methanococcus jannaschii Prot D (43/239), CP synthesis & Bult et al. (1996) \\
\hline $\operatorname{cap} 5(8) F$ & 371 & Acholeplasma laidlawii (58/369), putative nucleotide-binding protein & GenBank accession Z22875 \\
\hline $\operatorname{cap5}(8) G$ & 374 & $\begin{array}{l}\text { M. jannaschii Bp1D (46/70), lipopolysaccharide synthesis } \\
\text { Bo. pertussis Bp1D ( } 38 / 75) \text {, lipopolysaccharide synthesis } \\
\text { Escherichia coli } \mathrm{RffE}(35 / 64) \text {, UDP-GlcNAc } 2 \text {-epimerase } \\
\text { Salmonella enterica } \mathrm{RfbC}(35 / 60) \text {, UDP-GlcNAc } 2 \text {-epimerase } \\
\text { Pseudomonas solanacearum } \text { EpsC }(33 / 68) \text {, exopolysaccharide synthesis } \\
\text { Bacillus subtilis ORFX }(31 / 70)\end{array}$ & $\begin{array}{l}\text { Bult et al. (1996) } \\
\text { Allen \& Maskell (1996) } \\
\text { Meier-Dieter } \text { et al. (1990) } \\
\text { Keenleyside \& Whitfield (1996) } \\
\text { Huang \& Schell (1995) } \\
\text { Soldo } \text { et al. (1993) }\end{array}$ \\
\hline cap5H & 208 & E. coli Cat4 (42/88), chloramphenicol O-acetyltransferase & Parent \& Roy (1992) \\
\hline cap $8 H$ & 360 & None & \\
\hline cap5I & 369 & None & \\
\hline cap8I & 464 & None & \\
\hline $\operatorname{cap} 8 J$ & 185 & $\begin{array}{l}\text { R. meliloti NodL }(54 / 58) \text {, O-acetyltransferase } \\
\text { E. coli LacA }(48 / 45) \text {, thiogalactoside } O \text {-acetyltransferase }\end{array}$ & $\begin{array}{l}\text { Ardourel et al. (1995) } \\
\text { Hediger et al. (1985) }\end{array}$ \\
\hline cap5J & 338 & None & \\
\hline $\operatorname{cap} 5 \mathrm{~K}$ & 394 & None & \\
\hline $\operatorname{cap} 8 K$ & 412 & None & \\
\hline $\operatorname{cap} 5(8) L$ & 401 & E. coli WcaI $(39 / 41)$, probable glycosyltransferase & Stevenson et al. (1996) \\
\hline $\operatorname{cap} 5(8) M$ & 185 & $\begin{array}{l}\text { Sal. enterica } \mathrm{WbaP}(65 / 41) \text {, galactosyltransferase } \\
\text { Xanthomonas campestris GumD (64/34), galactosyltransferase } \\
\text { Streptococcus agalactiae CpsD (68/41), galactosyltransferase }\end{array}$ & $\begin{array}{l}\text { Wang et al. (1996) } \\
\text { Vanderslice } \text { et al. (1989) } \\
\text { Rubens et al. (1993) }\end{array}$ \\
\hline $\operatorname{cap} 5(8) N$ & 295 & $\begin{array}{l}\text { Salmonella typhimurium GalE ( } 32 / 75) \text {, UDP-Glc 4-epimerase } \\
\text { E. coli GalE (31/74), UDP-Glc 4-epimerase }\end{array}$ & $\begin{array}{l}\text { Houng et al. (1990) } \\
\text { Lemaire \& Muller-Hill (1986) }\end{array}$ \\
\hline $\operatorname{cap} 5(8) \mathrm{O}$ & 420 & $\begin{array}{l}\text { M. jannaschii M J0428 (62/126), UDP-ManNAc dehydrogenase } \\
\text { E. coli } \mathrm{RffD}(51 / 157) \text {, UDP-ManNAc dehydrogenase } \\
\text { P. solanacearum EpsD (51/208), exopolysaccharide synthesis } \\
\text { Pseudomonas aeruginosa AlgD (22/68), GDPmannose dehydrogenase }\end{array}$ & $\begin{array}{l}\text { Bult et al. }(1996) \\
\text { Daniels } \text { et al. }(1992) \\
\text { Huang \& Schell (1995) } \\
\text { Deretic et al. }(1987 \mathrm{a})\end{array}$ \\
\hline $\operatorname{cap} 5(8) P$ & 391 & $\begin{array}{l}\text { B. subtilis } \text { ORFX (59/373) } \\
\text { E. coli } \mathrm{RffE}(57 / 176) \text {, UDP-GlcNAc } 2 \text {-epimerase } \\
\text { P. solanacearum EpsC (48/220), exopolysaccharide synthesis } \\
\text { Sal. enterica } \mathrm{RfbC}(54 / 178) \text {, UDP-GlcNAc 2-epimerase }\end{array}$ & $\begin{array}{l}\text { Soldo et al. (1993) } \\
\text { Meier-Dieter } \text { et al. (1990) } \\
\text { Huang \& Schell (1995) } \\
\text { Keenleyside \& Whitfield (1996) }\end{array}$ \\
\hline
\end{tabular}

* Number of amino acids.

† Numbers in parentheses indicate percentage identity of amino acid sequence/length of the homologous region. 
CpsC of Streptococcus pneumoniae (Guidolin et al., 1994) (Table 2). EpsC is thought to be involved in chainlength determination because of the similarity of amino acid sequences and hydrophobicity profiles to several proteins involved in polysaccharide chain-length determination, including Cld of E. coli (Batchelor et al., 1992; Bastin et al., 1993), Rol of Salmonella enterica (Bastin et al., 1993), Rol of Shigella flexneri (Morona et al., 1995), and the N-terminal half of ExoP of Rhizobium meliloti (Becker et al., 1995). Although pairwise alignment of Cap5A or Cap8A to Cld Rol, or the N-terminal half of ExoP revealed only limited homology to the proposed conserved motif of these chain-length determinants, their hydrophobicity plots are similar, showing two potential membrane-spanning domains, one at either end, and a hydrophilic central region (not shown). Thus cap5A and cap8A could be involved in chainlength determination.

As shown in Table 2, Cap8B and Cap5B show significant homology to EpsD of Strep. thermophilus (Stingele et al., 1996), CpsD of Strep. pneumoniae (Guidolin et al., 1994) and the C-terminal half of ExoP of R. meliloti (Becker et al., 1995). All of these proteins contain the ATP-binding motif. ExoP is a large protein with 786 amino acids. The N-terminal half of ExoP has been implicated in chain-length determination of succinoglycan synthesis, whereas the C-terminal half appears to exert a regulatory function following nucleotide binding (Becker et al., 1995). As shown in Fig. 2(a), Cap8B and Cap5B also contain a conserved ATP-binding motif found in many bacterial transporter genes (Fath \& Kolter, 1993). The nucleotide-binding motif is composed of the A site, with conserved GXGKST at residues 52-57, and the B site, with a conserved aspartic acid residue at position 157 . Since Cap5(8)B exhibits significant homology with the conserved nucleotide-binding motif of the C-terminal half of ExoP, and since Cap5(8)A has a hydrophobicity profile similar to that of the N-terminal half of ExoP, it is likely that Cap5(8)B forms a complex with Cap5(8)A to regulate the chain length of CP5(8). A similar suggestion was first put forth with regard to Strep. thermophilus EpsC and EpsD by Stingele et al. (1996) who speculated that epsC and eps $D$, located next to each other like cap5(8)A and cap $5(8) B$, were originally one gene and were later separated or that exoP had evolved from a gene fusion. Recently, we found that a site-specific cap $8 B$ mutant produced the same amount of CP8 as wild-type strain Becker but that the CP8 of the mutant was of lower molecular mass (S. Sau \& C. Y. Lee, unpublished). This result is consistent with the proposed function of Cap8B as a chain-length regulator. Studies are in progress to confirm the function of $c a p 8 B$.

\section{Amino sugar synthesis genes}

The deduced proteins from cap5D and cap $8 D$ genes show a high degree of homology to several proteins in the databases that have not been characterized functionally. Nevertheless, these proteins show local homology to a number of proteins involved in the sugar synthetic pathways (most of which are UDP-Glc 4epimerases and UDP-Glc dehydratases). Skurnik et al. (1995) aligned 19 of these proteins and identified two conserved regions that may be essential for enzymic function. They proposed that Yersinia enterocolitica TrsG might be involved in the synthesis of GalNAcp or FucNAcp. Fig. 2(b) shows the alignment of some of these proteins at the regions near the two consensus regions. Since staphylococcal CP1, CP5 and CP8 all contain D-FucNAcp and since Cap1D, Cap5D and Cap8D are highly homologous, these three proteins could be epimerases or dehydratases involved in the synthesis of D-FucNAcp. Interestingly, we also found that the amino acid sequence of Cap5(8)D was moderately similar to the deduced sequences from cap $5 E$ and cap $8 E$ (Fig. 2b). The homologous regions include the two conserved motifs identified by Skurnik et al. (1995). Thus, it is possible that Cap5E and Cap8E work in concert with Cap5D and Cap8D, respectively, in the synthesis of D-FucNAcp.

Cap5F and Cap8F show highest homology to a protein from Acholeplasma laidlawii whose function is unknown. Cap5F and Cap8F also show limited homology (not shown), especially at the regions near the $\mathrm{N}$ terminal end, to several bacterial nucleotide sugar epimerases or dehydratases required for polysaccharide synthesis, including the RfbB proteins of $E$. coli (Marolda \& Valvano, 1995), Sh. flexneri (Macpherson et al., 1994) and Sal. enterica (Jiang et al., 1991). Therefore, we propose that Cap5F and Cap8F are either nucleotide sugar epimerases or dehydratases. Similarly, Cap5N and Cap8N may be epimerases involved in sugar conversion because of limited homology to various GalE (UDP-Glc 4-epimerase) proteins of $E$. coli (Lemaire \& Müller-Hill, 1986) and Salmonella typhimurium (Houng et al., 1990), especially at the N-terminal end (not shown).

It is interesting that Cap5(8)G and Cap5(8)P exhibit $29.0 \%$ overall identity; this observation suggests that the two proteins may have similar functions but with different substrates. Cap5P and Cap8P show high degrees of homology to several gene products in the databases (Table 2) including RffE of E. coli (MeierDieter et al., 1990) and RfbC of Sal. enterica (Keenleyside \& Whitfield, 1996), whereas Cap5(8)G show limited homology to these gene products. RffE has been shown to have 2-epimerase activity, catalysing the conversion of UDP-GlcNAc $p$ to UDP-ManNAc $p$ in the biosynthesis of enterobacterial common antigen, a surface glycolipid associated with all members of the Enterobacteriaceae (Meier-Dieter et al., 1990). RfbC of Sal. enterica serovar Borreze has been implicated as a UDP-GlcNAcp 2epimerase (Keenleyside \& Whitfield, 1996). Thus, it is likely that Cap5(8)G and Cap5(8)P are epimerases. Fig. 2(c) shows the alignment of Cap5G, Cap5P and the related proteins at the regions near the $\mathrm{N}$-terminal end.

Cap5O and Cap8O are similar to several proteins, including RffD of E. coli (Daniels et al., 1992) and AlgD of Pseudomonas aeruginosa (Deretic et al., 1987a). The E. coli rffD gene is involved in the biosynthetic pathway leading to enterobacterial common antigen expression. 


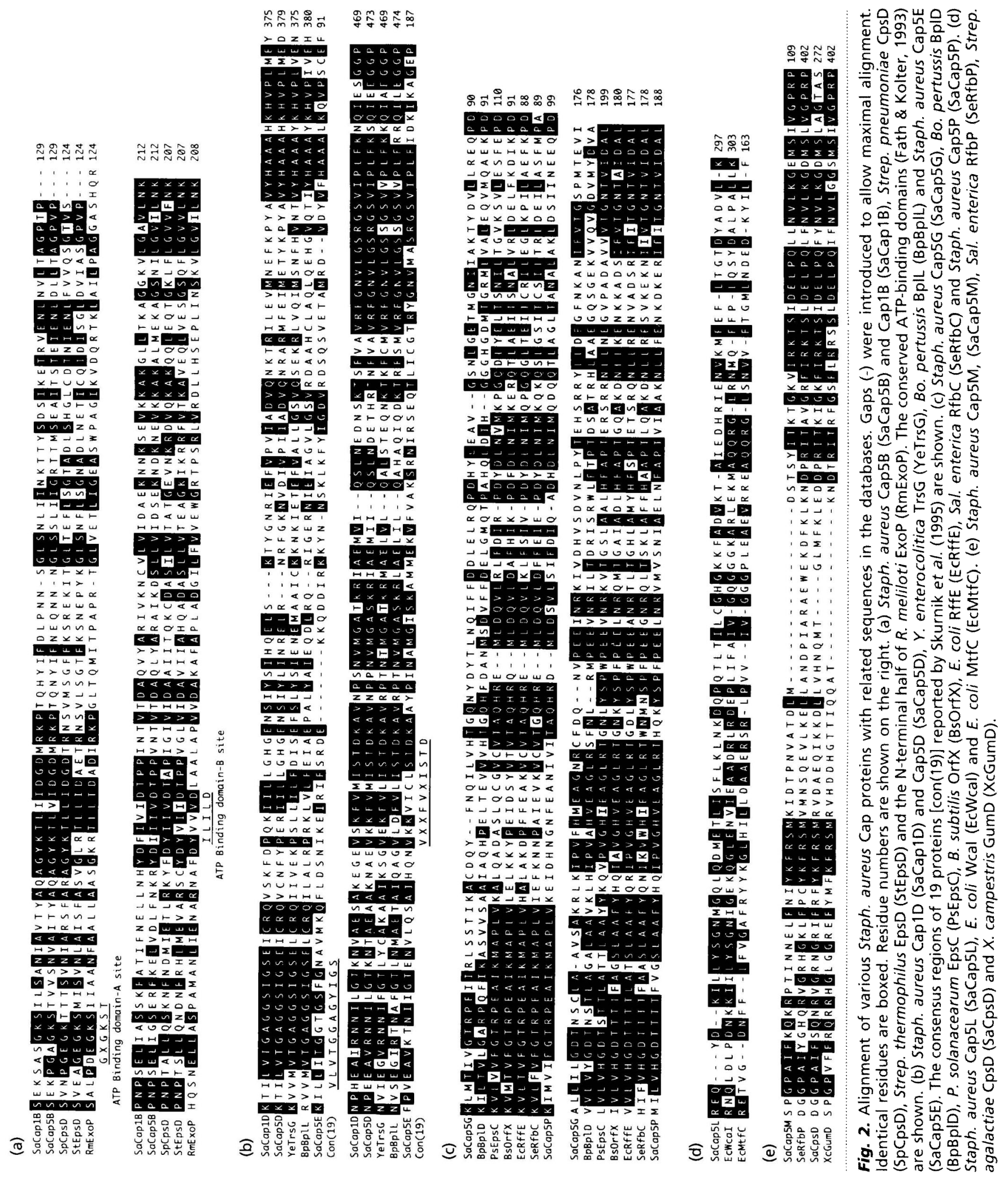


RffD has UDP-ManNAcp dehydrogenase activity, catalysing the conversion of UDP-ManNAcp to UDPManNAcAp (Meier-Dieter et al., 1990). AlgD of $P$. aeruginosa has been shown biochemically to be a GDPD-mannose dehydrogenase (Deretic et al., 1987b). Thus it is likely that Cap5O and Cap8O are dehydrogenases involved in synthesis of ManNAcAp, which is a component of both CP5 and CP8. In fact, cap5O complements an $r f f D$ mutation in an E. coli mutant defective in enterobacterial common antigen synthesis (K. Kiser $\&$ J. C. Lee, unpublished). The presence of NADbinding domains (Wierenga et al., 1986) in the $\mathrm{N}$ terminal ends of both Cap5O and Cap8O is in accordance with their proposed function as dehydrogenases that require NAD as a cofactor.

\section{Transferases}

Both Cap5L and Cap8L show limited homology (about $20 \%$ identity and $47.4 \%$ similarity over 365 amino acids) to WcaI of $E$. coli, a putative glycosyltransferase (Stevenson et al., 1996). The proposed function of WcaI was based on a low degree of homology to $\mathrm{MtfC}$, a mannosyltransferase for $E$. coli $\mathrm{O} 9$ antigen synthesis (Kido et al., 1995). Although Cap5L and Cap8L do not have significant homology to MtfC, limited local homology between Cap5L(Cap8L) and $\mathrm{MtfC}$ was detected (Fig. 2d). Thus, Cap5L and Cap8L are candidates for glycosyltransferases.

Cap5 $\mathrm{M}$ and Cap8M are homologous to many similarsize gene products in the databases that are thought to be glycosyltransferases. These two proteins are also homologous to the C-terminal half of a group of larger proteins, including WbaP (RfbP) of Sal. enterica (Wang et al., 1996), CpsD of Streptococcus agalactiae (Rubens et al., 1993) and GumD of Xanthomonas campestris (Ielpi et al., 1993; Vanderslice et al., 1989), which all have galactosyltransferase activity. In the case of WbaP, the transferase activity is located in the C-terminal half of the protein to which Cap5M and Cap8M show a high degree of homology. The alignment of these proteins is shown in Fig. 2(e). In addition, the C-terminal half of WhaP contains a potential transmembrane domain; a similar hydropathic profile was found in Cap5M and Cap8M (not shown). On the basis of these findings, we propose that Cap5M and Cap8M are glycosyltransferases.

The cap5I and cap8H genes are located in the typespecific central regions of the cap5 and cap8 gene clusters, respectively. The predicted proteins show no homology to the reported proteins in the databases. Both Cap5I and Cap8H are hydrophilic, and the hydrophobicity profiles of the two resemble each other (not shown). Because cap5I and cap8H are type-specific genes, they may be transferase genes that provide either the serotype-specific linkage between ManNAcA $p$ and L-FucNAc $p$ or between D-FucNAcp and the adjacent ManNAcA $p$ residues.

\section{0 -acetylation genes}

Although Cap5H and Cap8J show little overall homology ( $27 \%$ identity over a region of 94 amino acids), they are similar at a region of about 50 amino acids that is located near the C-terminus of the protein. This consensus region is found in members of the NodLLacA-CysE acetyltransferase family (Downie, 1989) including Cap1G, which is required for staphylococcal CP1 synthesis (Lin et al., 1994). Cap5H is involved in Oacetylation of the third carbon of the mannosaminuronic acid residue of CP5 in Staph. aureus strain Reynolds Lee et al., 1995). By analogy, Cap8J is likely to be an acetyltransferase involved in $\mathrm{O}$-acetylation of the fourth carbon of mannosaminuronic acid of CP8. Although it is somewhat surprising that the three putative staphylococcal acetyltransferases are so dissimilar in terms of overall homologies, this dissimilarity is indicative of the substrate specificities of these enzymes.

\section{Polymerization and export genes}

Bacterial polysaccharides may be synthesized on the cytoplasmic side of the membrane and then transported through the membrane by an $\mathrm{ABC}$ transporter enzyme. Alternatively, repeating subunits may be synthesized on the inner side of the membrane, transported to the outer side, and then polymerized (Whitfield, 1995). An example of the latter mechanism is the O-antigen transport of Sal. enterica group B O-antigen (Whitfield, 1995). An enzyme termed flippase, Wzx (formerly $\mathrm{RfbX}$, is required for flipping the lipid-bound $\mathrm{O}$ subunit from the cytoplasmic side to the periplasmic side of the membrane, where it is polymerized by another membrane-bound $\mathrm{O}$-antigen polymerase, $\mathrm{Rfc}$ (Liu et al., 1996; Morona et al., 1994). Wzx and Rfc are predicted to be integral membrane proteins with 12 transmembrane domains. However, little or no sequence homology was found among $w z x$ genes or among $\mathrm{O}$ antigen polymerases of different $\mathrm{O}$-antigen gene clusters (Morona et al., 1994).

Among the predicted proteins of cap5 and cap 8 loci, Cap5J, Cap5K, Cap8I, and Cap8K contain possible multiple transmembrane domains. The hydrophobicity profiles (not shown) of Cap5J and Cap8I are very similar with 10 possible transmembrane domains, though they show only $17 \cdot 1 \%$ identity over 340 amino acids. Similarly, the hydrophobicity profiles of Cap5K and Cap8K are nearly identical, with 11 possible transmembrane domains, and yet the primary amino acid sequences are quite different (with $19.8 \%$ identity over 303 amino acids). Despite no similarity to known flippases or polymerases, the transmembrane domains found in these proteins are consistent with the postulation that Cap5J(Cap8I) and Cap5K(Cap8K) may be a pair of membrane-bound flippases and polymerases involved in $\mathrm{CP} 5(8)$ synthesis. Moreover, the failure to find an $\mathrm{ABC}$ transporter (containing an ATP-binding cassette and multiple transmembrane domains) in the 
(a)

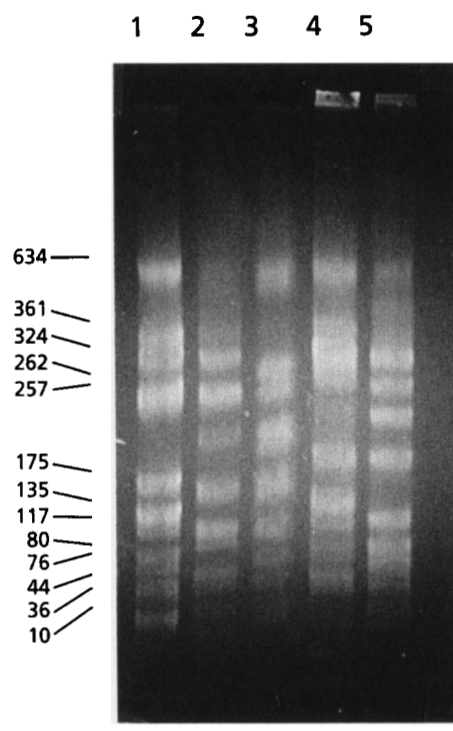

(b)
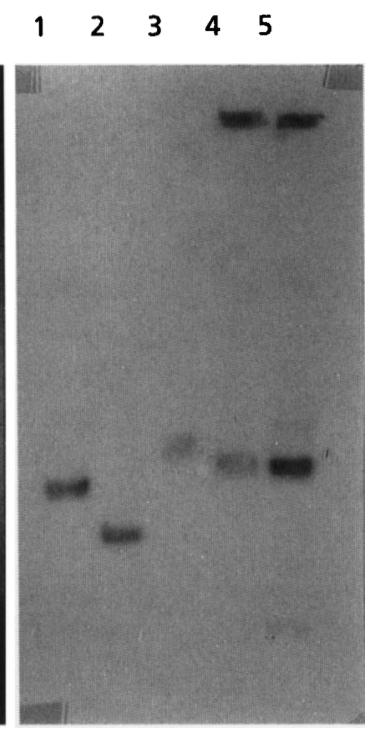

Fig. 3. Mapping of the cap5(8) locus. (a) Chromosomal DNAs were digested with $\mathrm{Smal}$ and resolved in $0.8 \%$ agarose gel as described by Goering \& Winters (1992). (b) The resolved DNA fragments from (a) were transferred to nitrocellulose paper and probed with an $\sim 8.5 \mathrm{~kb}$ cap8-specific DNA fragment (from about 2 to $10.5 \mathrm{~kb}$ coordinates in Fig. 1). Lanes: 1, strain NCTC 8325 ; 2, strain $M$; 3, strain Smith; 4, strain Reynolds; 5 , strain Becker. Numbers to the left of the figure indicate the sizes of the Smal fragment from NCTC 8325 in kb. Note that strains M (serotype 1) and Smith (serotype 2) also contain the cap8related DNA (Sau \& Lee, 1996).

cap5 or cap8 loci of Staph. aureus indicates that staphylococcal capsules of types 5 and 8 may be exported by a flippase-polymerase mechanism.

\section{Other genes}

The Cap5C and Cap8C sequences show a moderate degree of homology to EpsB of Strep. thermopbilus (Stingele et al., 1996) and to Cps19fB of Strep. pneumoniae (Guidolin et al., 1994) but neither of these has been functionally characterized. We therefore cannot assign any function to cap5(8)C.

\section{Mapping of the cap5 and cap8 gene clusters}

The nearly identical nucleotide sequences of the cap5 and cap 8 gene clusters at two regions that flank the central type-specific regions indicate that cap5 and cap 8 loci are allelic. To determine the location of this allele on the Staph. aureus genome, we performed field-inversion gel electrophoresis of SmaI-digested DNAs from strain Becker, strain Reynolds and the mapping strain NCTC 8325. The resolved DNA fragments were transferred to nitrocellulose paper and probed with a DNA fragment internal to the cap8 operon (Fig. 3). We found that cap5 and cap 8 gene clusters mapped to the SmaI-G fragment of the physical map of strain NCTC 8325 (Pattee et al., 1992). Interestingly, the cap1 gene cluster, which is not

allelic to the cap8 locus (Sau \& Lee, 1996), was also mapped to the same SmaI-G fragment (S. Ouyang \& C. Y. Lee, unpublished data). Thus, the cap1 and cap5(8) loci indeed map close together within a $175 \mathrm{~kb}$ region of the chromosome.

\section{Conclusion}

The functions that we have predicted for the cap5 and cap8 genes are based on amino acid sequence homologies with genes in the databases. Biochemical evidence is required to confirm these proposed functions. Nevertheless, our predictions are in accord with the chemical structures of the capsules, allowing us to propose a preliminary synthetic pathway for CP5 and CP8. The repeating unit of CP5(CP8) is composed of three sugars: D-ManNAcA $p$, L-FucNAc $p$ and DFucNAcp. We propose that these sugars are derived from a nucleotide precursor of $\mathrm{D}-$ GlcNAcp by a number of epimerases and dehydratases encoded by cap5 5$) D, E$, $F, G, N, O$ and $P$. One of the sugars, D-ManNAcA $p$, is further $\mathrm{O}$-acetylated by $\mathrm{Cap} 5 \mathrm{H}(\mathrm{Cap} 8 \mathrm{~J})$. The three sugar monomers are transferred by three transferases, Cap5(8)L, Cap5(8)M and Cap5I(Cap8H), to form a repeating unit possibly linked to a lipid carrier at the inner side of the cytoplasmic membrane. The lipidlinked repeating unit is then transported through the membrane and polymerized at the outer surface of the membrane by Cap5J(Cap8I) and Cap $5(8) \mathrm{K}$ with the aid of the chain-length determinators $\mathrm{Cap} 5(8) \mathrm{A}$ and Cap5(8)B. Of all the predicted gene products, Cap5(8)C is the only one to which we were unable to assign any function. However, since Cap5C and Cap8C show very strong homology with Cap1C, it is tempting to speculate that they are involved in a process common to CP5, CP8 and $\mathrm{CP} 1$ synthesis, such as transport. Our current efforts are directed at obtaining biochemical evidence to support the gene functions that we have proposed herein.

\section{ACKNOWLEDGEMENTS}

We thank Paul Livolsi for technical assistance and Michael Coyne for helpful suggestions. This work was supported by grants AI37027 (to C.Y.L.) and AI29040 (to J.C.L.) from the NIH, and by the Health Research Board of Ireland (to T.J.F and E.R.W.).

\section{REFERENCES}

Albus, A., Fournier, J. M., Wolz, C., Boutonnier, A., Ranke, M., Hoiby, N., Hochkeppel, H. \& Doring, G. (1988). Staphylococcus aureus capsular types and antibody response to lung infection in patients with cystic fibrosis. J Clin Microbiol 26, 2205-2209.

Albus, A., Arbeit, R. D. \& Lee, J. C. (1991). Virulence of Staphylococcus aureus mutants altered in type 5 capsule production. Infect Immun 59, 1008-1014.

Allen, A. \& Maskell, D. (1996). The identification, cloning and mutagenesis of a genetic locus required for lipopolysaccharide biosynthesis in Bordetella pertussis. Mol Microbiol 19, 37-52.

Altschul, A. F., Gish, W., Miller, W., Myers, E. W. \& Lipman, D. J. (1990). Basic local alignment search tool. J Mol Biol 215, 403-410. 
Arbeit, R. D., Karakawa, W. W., Vann., W. F. \& Robbins, J. B. (1984). Predominance of two newly described capsular polysaccharide types among clinical isolates of Staphylococcus aureus. Diagn Microbiol Infect Dis 2, 85-91.

Ardourel, M., Lortet, G., Maillet, F., Roche, P., Truchet, G., Promé, J. C. \& Rosenberg, C. (1995). In Rhizobium meliloti, the operon associated with the nod box $\mathrm{n} 5$ comprises nodL, noe $A$ and noeB, three host-range genes specifically required for the nodulation of particular Medicago species. Mol Microbiol 17, 687-699.

Baddour, L. M., Lowrance, C., Albus, A., Lowrance, J. H., Anderson, S. K. \& Lee, J. C. (1992). Staphylococcus aureus microcapsule expression attenuates bacterial virulence in a rat model of experimental endocarditis. J Infect Dis 165, 749-753.

Bastin, D. A., Stevenson, G., Brown, P. K., Haase, A. \& Reeves, P. (1993). Repeat unit polysaccharides of bacteria: a model for polymerization resembling that of ribosomes and fatty acid synthetase, with a novel mechanism for determining chain length. Mol Microbiol 7, 725-734.

Batchelor, R. A., Alifano, P., Biffali, E., Hull, S. \& Hull, R. (1992). Nucleotide sequences of the genes regulating O-polysaccharide antigen chain length (rol) from Escherichia coli and Salmonella typhimurium: protein homology and functional complementation. J Bacteriol 174, 5228-5236.

Becker, A., Niehaus, K. \& Puhler, A. (1995). Low-molecularweight succinoglycan is predominantly produced by Rizobium meliloti strains carrying a mutated ExoP protein characterized by a periplasmic $\mathrm{N}$-terminal domain and a missing C-terminal domain. Mol Microbiol 16, 191-203.

Birnboim, H. C. (1983). A rapid alkaline extraction method for the isolation of plasmid DNA. Methods Enzymol 100, 243-255.

Bult, C. J., White, O., Olsen, G. J. \& 37 other authors (1996). Complete genome sequence of the methanogenic Archaeon, Methanococcus jannaschii. Science 273, 1058-1073.

Comstock, L. E., Johnson, J. A., Michalski, J. M., Morris, J. G., Jr \& Kaper, J. B. (1996). Cloning and sequence of a region encoding a surface polysaccharide of Vibrio cholerae $\mathrm{O} 139$ and characterization of the insertion site in the chromosome of Vibrio cholerae O1. Mol Microbiol 19, 815-826.

Daniels, D. L, Plunkett, G., III, Burland, V. \& Blattner, F. R. (1992). Analysis of the Escherichia coli genome: DNA sequence of the region from $84 \cdot 5$ to 86.5 minutes. Science $257,771-778$.

Deretic, V., Gill, J. F. \& Chakrabarty, A. M. (1987a). Pseudomonas aeruginosa infection in cystic fibrosis: nucleotide sequence and transcriptional regulation of the algD gene. Nucleic Acids Res 15, $4567-4581$.

Deretic, V., Gill, J. F. \& Chakrabarty, A. M. (1987b). Gene algD coding for GDP-mannose dehydrogenase is transcriptionally activated in mucoid Pseudomonas aeruginosa. J Bacteriol 169, 351-358.

Downie, J. A (1989). The nodL gene from Rhizobium leguminosarum is homologous to the acetyl transferases encoded by lacA and cysE. Mol Microbiol 3, 1649-1651.

Fath, M. \& Kolter, R. (1993). ABC transporters: bacterial exporters. Microbiol Rev 57, 995-1017.

Fattom, A. I., Sarwar, J., Ortiz, A. \& Naso, R. (1996). A Staphylococcus aureus capsular polysaccharide $(\mathrm{CP})$ vaccine and $\mathrm{CP}$-specific antibodies protect mice against bacterial challenge. Infect Immun 64, 1659-1665.

Fournier, J. M., Vann, W. F. \& Karakawa, W. W. (1984). Purification and characterization of Staphylococcus aureus type 8 capsular polysaccharide. Infect Immun 45, 87-93.

Goering, R. V. \& Winters, M. A. (1992). Rapid method for epidemiological evaluation of gram-positive cocci by field inversion gel electrophoresis. J Clin Microbiol 30, 577-580.

Guidolin, A., Morona, J. K., Morona, R., Hansman, D. \& Paton, J. (1994). Nucleotide sequence analysis of genes essential for capsular polysaccharide biosynthesis in Streptococcus pneumoniae type 19F. Infect Immun 62, 5384-5396.

Hanessian, S. \& Haskell, T. H. (1964). Structural studies on staphylococcal polysaccharide antigens. J Biol Chem 239, 2758-2764.

Hediger, M. A, Johnson, D. F., Nierlich, D. P. \& Zabin, I. (1985). DNA sequence of the lactose operon: the lacA gene and the transcriptional termination region Proc Natl Acad Sci USA 82, $6414-6418$.

Higgins, D. G. \& Sharp, P. M. (1988). CluSTAL: a package for performing multiple sequence alignments on a microcomputer. Gene 73, 237-244.

Hochkeppel, H. K., Braun, D. G., Vischer, W., Imm, A., Sutter, S., Staeubli, U., Guggenheim, R., Kaplan, E. L., Boutonnier, A. \& Fournier, J. M. (1987). Serotyping and electron microscopy studies of Staphylococcus aureus clinical isolates with monoclonal antibodies to capsular polysaccharide type 5 and type $8 . \mathrm{J} \mathrm{Clin}$ Microbiol 25, 526-530.

Houng, H. H.-S., Kopecko, D. \& Baron, L. S. (1990). Molecular cloning and physical and functional characterization of the Salmonella typhimurium and Salmonella typhi galactose utilization operons. J Bacteriol 172, 4392-4398.

Huang, J. \& Schell, M. (1995). Molecular characterization of the eps gene cluster of Pseudomonas solanacearum and its transcriptional regulation at a single promoter. Mol Microbiol 16, 977-989.

lelpi, L., Couso, R. O. \& Dankert, M. A. (1993). Sequential assembly and polymerization of the polyprenol-linked pentasaccharide repeat unit of the xanthan polysaccharide in Xanthomonas campestris. J Bacteriol 175, 2490-2500.

Jiang, X.-M., Santiago, N. R., Lee, S. L., Romana, L. K. \& Reeves, P. R. (1991). Structure and sequence of the $r f b$ ( $O$ antigen) gene cluster of Salmonella serovar typhimurium (strain LT2). Mol Microbiol 5, 695-713.

Karakawa, W. W. \& Vann, W. F. (1982). Capsular polysaccharides of Staphylococcus aureus. Semin Infect Dis 4, 285-293.

Karakawa, W. W., Fournier, J. M., Vann, W. F., Arbeit, R., Schneerson, R. \& Robbins, J. B. (1985). Method for the serological typing of the capsular polysaccharides of Staphylococcus aureus. $J$ Clin Microbiol 22, 445-447.

Karakawa, W. W., Sutton, A., Schneerson, R., Karpas, A. \& Vann, W. F. (1988). Capsular antibodies induce type-specific phagocytosis of Staphylococcus aureus by human polymorphonuclear leukocytes. Infect Immun 56, 1090-1095.

Keenleyside, W. J. \& Whitfield, C. (1996). A novel pathway for O-polysaccharide biosynthesis in Salmonella enterica serovar Borreze. J Biol Chem 271, 28581-28592.

Kido, N., Torgov, V. I., Sugiyama, T., Uchiya, K., Sugihara, H., Komatsu, T., Kato, N. \& Jann, K. (1995). Expression of the O9 polysaccharide of Escherichia coli: sequencing of the E. coli O9 $r f b$ gene cluster, characterization of mannosyl transferases, and evidence for an ATP-binding cassette transport system. J Bacteriol 177, 2178-2187.

Klein, P., Kanehisa, M. \& Delisi, C. (1985). The detection and classification of membrane-spanning proteins. Biochim Biophys Acta 815, 468-476.

Kyte, J. \& Doolittle, R. F. (1982). A simple method for displaying the hydropathic character of a protein. J Mol Biol 157, 105-132. 
Lee, C. Y. (1992). Cloning of genes affecting capsule expression in Staphylococcus aureus strain M. Mol Microbiol 6, 1515-1522.

Lee, C. Y., Buranen, S. L. \& Ye, Z. H. (1991). Construction of single-copy integration vectors for Staphylococcus aureus. Gene $103,101-105$.

Lee, J. C., Betley, M. J., Hopkins, C. A., Perez, N. E. \& Pier, G. B. (1987). Virulence studies, in mice, of transposon-induced mutants of Staphylococcus aureus differing in capsule size. $J$ Infect Dis 156, 741-750.

Lee, J. C., Xu, S., Albus, A. \& Livolsi, P. J. (1994). Genetic analysis of type 5 capsular polysaccharide expression by Staphylococcus aureus. J Bacteriol 176, 4883-4889.

Lee, J. C., Albus, A. \& Livolsi, P. J. (1995). Identification of a gene essential for O-acetylation of the Staphylococcus aureus type 5 capsular polysaccharide. In Abstracts of the 95th Annual Meeting of the American Society for Microbiology, abstract no. B453. Washington, DC: American Society for Microbiology.

Lee, J. C., Park, J.-S., Shepherd, S. E. \& Fattom, A. (1996). Protective efficacy of antibodies to the Staphylococcus aureus capsular polysaccharides to a rat model of endocarditis. In Abstracts of the 96th Annual Meeting of the American Society for Microbiology, abstract no. B328. Washington, DC: American Society for Microbiology.

Lemaire, H.-G. \& Müller-Hill, B. (1986). Nucleotide sequences of the galE gene and the galT gene of E. coli. Nucleic Acids Res 14, $7705-7711$.

Lin, W. S., Cunneen, T. \& Lee, C. Y. (1994). Sequence analysis and molecular characterization of genes required for the biosynthesis of type 1 capsular polysaccharide in Staphylococcus aureus. J Bacteriol 176, 7005-7016.

Liu, D., Cole, R. A. \& Reeves, P. R. (1996). An O-antigen processing function for $W_{z x}(R f b X)$ : a promising candidate for O-unit flippase. J Bacteriol 178, 2102-2107.

Macpherson, D. F., Manning, P. A. \& Morona, R. (1994). Characterization of the dTDP-rhamnose biosynthetic genes encoded in the $r f b$ locus of Shigella flexneri. Mol Microbiol 11, 281-292.

Marolda, C. L. \& Valvano, M. A. (1995). Genetic analysis of the dTDP-rhamnose biosynthesis region of the Escherichia coli VW187 (O7:K1) rfb gene cluster: identification of functional homologs of $r f b B$ and $r f b A$ in the $r f f$ cluster and correct location of the rffE gene. J Bacteriol 177, 5539-5546.

Meier-Dieter, U., Starman, R., Barr, K., Mayer, H. \& Rick, P. D. (1990). Biosynthesis of enterobacterial common antigen in Escherichia coli. J Biol Chem 265, 13490-13497.

Melly, M. A., Duke, L. J., Liau, D. F. \& Hash, J. H. (1974). Biological properties of the encapsulated Staphylococcus aureus M. Infect Immun 10, 389-397.

Moreau, M., Richards, J. C., Fournier, J. M., Byrd, R. A., Karakawa, W. W. \& Vann, W. F. (1990). Structure of the type-5 capsular polysaccharide of Staphylococcus aureus. Carbohydr Res 201, 285-297.

Morona, R., Mavris, M., Fallarino, A. \& Manning, P. A. (1994). Characterization of the $r f c$ region of Shigella flexneri. J Bacteriol 176, 733-747.

Morona, R., van den Bosch, L. \& Manning, P. A. (1995). Molecular, genetic, and topological characterization of $\mathrm{O}$-antigen chain length regulation in Shigella flexneri. J Bacteriol 177, 1059-1068.

Murthy, S. V. K. N., Melly, M. A., Harris, T. M., Hellerqvist, C. G. \& Hash, J. H. (1983). The repeating sequence of the capsular polysaccharide of Staphylococcus aureus. Carbohydr Res 117, 113-123.
Nemeth, J. \& Lee, J. C. (1995). Antibodies to capsular polysaccharides are not protective against experimental Staphylococcus aureus endocarditis. Infect Immun 63, 375-380.

Oeding, P. (1983). Taxonomy and identification. In Staphylococci and Staphylococcal Infections, pp. 1-32. Edited by C.S. G. Easmon \& G. Adlam. New York: Academic Press.

Parent, R. \& Roy, P. H. (1992). The chloramphenicol acetyltransferase gene of Tn2424: a new breed of cat. J Bacteriol 174, 2891-2897.

Pattee, P. A., Lee, H. C. \& Bannantine, J. P. (1992). Genetic and physical mapping of the chromosome of Staphylococcus aureus. In Molecular Biology of the Stapbylococci, pp. 41-67. Edited by R. P. Novick. New York: VCH.

Peterson, P. K., Wilkinson, B. J., Kim, Y., Schmeling, D. \& Quie, P. G. (1978). Influence of encapsulation on staphylococcal opsonization and phagocytosis by human polymorphonuclear leukocytes. Infect Immun 19, 943-949.

Poutrel, B., Boutonnier, A., Sutra, L. \& Fournier, J. M. (1988). Prevalence of capsular polysaccharide types 5 and 8 among Staphylococcus aureus isolates from cow, goat, and ewe milk. J Clin Microbiol 26, 38-40.

Rubens, C. E., Heggen, L. M., Haft, R. G. \& Wessels, M. R. (1993). Identification of $c p s D$, a gene essential for type III capsule expression in group B streptococci. Mol Microbiol 8, 844-855.

Sambrook, J., Fritsch, E. F. \& Maniatis, T. (1989). Molecular Cloning : a Laboratory Manual, 2nd edn. Cold Spring Harbor, NY: Cold Spring Harbor Laboratory.

Sanger, F., Nicklen, S. \& Coulson, A. R. (1977). DNA sequencing with chain-terminating inhibitors. Proc Natl Acad Sci USA 74, 5463-5467.

Sau, S. \& Lee, C. Y. (1996). Cloning of type 8 capsule genes and analysis of gene clusters for the production of different capsular polysaccharides in Staphylococcus aureus. J Bacteriol 178, 2118-2126.

Sau, S., Sun, J. \& Lee, C. Y. (1997). Molecular characterization and transcriptional analysis of type 8 genes in Staphylococcus aureus. J Bacteriol 179, 1614-1621.

Skurnik, M., Venho, R., Toivanen, P. \& Al-Hendy, A. (1995). A novel locus of Yersinia enterocolitica serotype $0: 3$ involved in lipopolysaccharide outer core biosynthesis. Mol Microbiol 17, 575-594.

Soldo, B., Lazarevic, V., Margot, P. \& Karamata, D. (1993). Sequencing and analysis of the divergon comprising gtaB, the structural gene of UDP-glucose pyrophosphorylase of Bacillus subtilis 168. J Gen Microbiol 139, 3185-3195.

Sompolinsky, E., Samra, Z., Karakawa, W. W., Vann, W. F., Schneerson, R. \& Malik, Z. (1985). Encapsulation and capsular types in isolates of Staphylococcus aureus from different sources and relationship to phage types. J Clin Microbiol 22, 828-834.

Stevenson, G., Andrianopoulos, K., Hobbs, M. \& Reeves, P. R. (1996). Organization of the Escherichia coli K-12 gene cluster responsible for production of the extracellular polysaccharide colanic acid. J Bacteriol 178, 4885-4893.

Stingele, F., Neeser, J.-R. \& Mollet, B. (1996). Identification and characterization of the eps (exopolysaccharide) gene cluster from Streptococcus thermophilus Sfi6. J Bacteriol 178, 1680-1690.

Vanderslice, R. W., Doherty, D. H., Capage, M. A., Betlach, M. R., Hassler, R. A., Henderson, N. M., Ryan-Graniera, J. \& Techlenberg, M. (1989). Genetic engineering of polysaccharide structure in Xanthomonas campestris. In Biomedical and Biotechnological Advances in Industrial Polysaccharides, pp. 145-156. Edited by V. Crescenzi, I. C. M. Dea, S. Paoletti, S. 
Stivala \& I. Sutherland. New York: Godon \& Breach Science Publishers.

Wang, L., Liu, D. \& Reeves, P. R. (1996). C-terminal half of Salmonella enterica WbaP (RfbP) is the galactosyl-1-phosphate transferase domain catalyzing the first step of $\mathrm{O}$-antigen synthesis. $J$ Bacteriol 178, 2598-2604.

Whitfield, C. (1995). Biosynthesis of lipopolysaccharide $O$ antigens. Trends Microbiol 3, 178-185.

Wierenga, R. K., Terpstra, P. \& Hol, W. G. J. (1986). Prediction of the occurrence of the ADP-binding $\beta \alpha \beta$-fold in proteins, using an amino acid sequence fingerprint. $J \mathrm{Mol}$ Biol 187, 101-107.

Wilkinson, B. J. (1983). Staphylococcal capsules and slime. In
Staphylococci and Staphylococcal Infections, pp. 481-523. Edited by C. S. G. Easmon \& G. Adlam. New York: Academic Press.

Xu, S., Arbeit, R. D. \& Lee, J. C. (1992). Phagocytic killing of encapsulated and microencapsulated Staphylococcus aureus by human polymorphonuclear leukocytes. Infect Immun 60, 1358-1362.

Yanisch-Perron, C., Vieira, J. \& Messing, J. (1985). Improved M13 phage cloning vectors and host strains: nucleotide sequences of the M13mp18 and pUC19 vectors. Gene 33, 103-119.

Received 31 December 1996; revised 21 February 1997; accepted 21 March 1997. 